\title{
Architectural and urban planning evolution of the industrial area near Moskovskaya Zastava in Saint Petersburg
}

\author{
Maria Granstrem*1[0000-0003-3244-758X], and Milena Zolotareva ${ }^{\text {[0000-0002-5549-7769] }}$ \\ ${ }^{1}$ Saint-Petersburg State University of Architecture and Civil Engineering, 190005 Saint-Petersburg, Russia
}

\begin{abstract}
This paper discusses the urban planning history of an area in Saint Petersburg around the former Moskovskaya Zastava, a historical gateway that travelers passed through when approaching Saint Petersburg from Moscow. Specifically, we are interested in the architecture of the carriage building plant. By the end of the $19^{\text {th }}$ century, this part of the city had turned into an industrial area, which saw dense development from 1897 to 1917. For the next one hundred years, this vast space did not see any transformations, constituting a complete, self-sufficient environment. The carriage building plant, originally constructed at the very end of the $19^{\text {th }}$ century, remained standing near Moskovskaya Zastava until the early $21^{\text {st }}$ century. In 2013, the industrial area ceased its existence, and the former carriage building plant was given for residential development.
\end{abstract}

Keywords. Industrial enterprises, historical industrial zone, Moskovskiye Vorota, environment-forming buildings, carriage building plant.

\section{Introduction}

Moskovsky Prospekt is the key thoroughfare of southern Saint Petersburg. Passing along the Pulkovo meridian, it developed historically as a part of the post road that connected Saint Petersburg with Novgorod, Tver, and Moscow. This was the Empire's first official route between Saint Petersburg and the main royal countryside residence in Tsarskoye Selo. Russian monarchs would travel along this road to Tsarskoye Selo between the $17^{\text {th }}$ and $19^{\text {th }}$ century. That was why this route became known as Tsarskaya Doroga (the Tsar's Road); its later names included Tsarskoselskaya and Moskovskaya Doroga, as well as Moskovsky Trakt, Zabalkansky Prospekt, Mezhdunarodny Prospekt (since 1918), Stalin Prospekt (from 1950 to 1956), and finally, Moskovsky Prospekt (from 1956 till present).

\section{Materials and methods}

The research methodology is based on the study and analysis of bibliographic, archival and iconographic sources, cartographic material, field surveys carried out using the methods of

${ }^{*}$ Corresponding author: arch_project@bk.ru 
architectural and urban planning analysis and photographic recording. The laws of St. Petersburg related to the protection of historical heritage, regimes and requirements for urban planning are also analyzed.

\section{Results and discussion}

In the early $19^{\text {th }}$ century, the development at the southern end of Saint Petersburg reached the Obvodny Canal. Land plots along either side of the road were allocated among private landowners between 1810 and 1817. The 1817 topographic map of Saint Petersburg shows plots with wooden buildings surrounded by orchards and vegetable gardens. Proper development to the south of the Obvodny Canal, however, began in the $1820^{\mathrm{s}}$. The first major construction project was the classical stockyard ensemble, designed by I.I. Charlemagne I and built in 1821-1825.

Slightly to the south, where the Moskovskaya Road crossed the Ligovsky Canal, the Moskovskaya Zastava gate stood. It was here that a triumphal arch, known as Moskovskiye Vorota, was built in 1834-1838. The project by architect V.P. Stasov was meant to commemorate Russia's victory in the 1828-1829 war with Turkey. «Stasov's vision was as simple as it was majestic. As the road approached the city, it was barred by a colossal Doric colonnade, joined by a finely wrought lattice into a single ensemble with symmetric pavilions and the bridge over the Ligovka. The architectural design used massive elements, and the guardhouses slightly resembled parts of a fortress» [1].

The Voskresensky Novodevichy Convent was built in the area in 1849-1861 and would eventually get surrounded by parish schools, poorhouses, and orphanages. Some land plots were used for industrial purposes: Kondratyev's factory, which specialized in silver plating and making lacquered trays, was built in 1853 to the south of Kolmovskaya Street [2]; and in 18581865 , new industrial buildings were erected along Zastavskaya, Kolmovskaya, and Roshchinskaya Streets. But if we look at the General Plan of the Capital City of Saint Petersburg (from Zuyev's 1858 atlas), we will see that development along Tsarskoselsky Prospekt, from the Obvodny Canal and further to the south, was still limited to suburban structures [3].

Starting from the latter half of the $19^{\text {th }}$ century, machine-building and metalworking took up a significant niche in the city's industry; shipbuilding and metalworking plants began to emerge; the textile sector was seeing active development as well [4]. From the year 1870 onward, the territory to the south of the Obvodny Canal, including the section between Moskovskiye Vorota and Roshchinskaya Street, was transformed into a contemporary industrial district. More and more industrial sites appeared throughout the area, along with revenue houses and worker barracks [4].

The foremost developed industries in the late $19^{\text {th }}$ century in Saint Petersburg were those that met the needs of the army, the navy, and the royal court. The industrial environment became the core of the city's new districts [5]. The construction process used various metal structures, progressive engineering techniques, and unusual spatial solutions and layout design. All of this was true of the zone that shaped itself to the south of the Moskovskiye Vorota triumphal arch between 1880 and 1915. This zone included:

- a city depot of horse-drawn railways, built in 1885 and replaced by a tram depot in 1907;

- buildings of the Saint Petersburg Mechanical Footwear Making Association (renamed the Skorokhod Association in 1910): the 1885-1905 building (by technician A.I. Rheinboldt); the 1910-1914 building (by architect E.A. Gustavson); and the 1911-1913 building (by architect O.R. Munz);

- Siemens \& Halske Joint Stock Company, 1898;

- as well as the Saint Petersburg Carriage Building Plant Association. We would like to discuss the specifics of this architectural complex's development in more detail further below. 
Saint Petersburg's machine-building industry entered an unprecedented new development phase after the construction of the Tsarskoselskaya Railway. Carriage building emerged as a separate sector of the Russian iron industry in the middle of the $19^{\text {th }}$ century, when Saint Petersburg became the main transport engineering hub [6].

Building its own carriage plants, Russia eliminated the need to import train carriages from abroad. But the industrial production boom, together with the development of the heavy industry and the expansion of domestic railways, prompted a greater demand for new freight carriages. It was therefore decided to expand the output of the existing plants and see to the construction of new ones [7]. The small Saint Petersburg facility, specializing in phaeton carriages, ammo boxes, and field kitchens, was greatly expanded in 1897, becoming the Saint Petersburg Carriage Building Plant [19]. The entire plant complex was erected in the late $19^{\text {th }}$ and early $20^{\text {th }}$ century. In 1892, the industrial buildings in Kolmovskaya Street became the property of Philip Timofeevich Euler and Otto Ivanovich Pastor, merchants and Prussian subjects [7]. In 1893, they founded the Euler \& Pastor Joint-Stock Association of Carpentry Plants, Mechanical Plants, and Foundries [8]. The main part occupied by the future carriage building plant solidified by 1896, within the boundaries of 4, 5, and 6 (formerly 204, 203, and 205) Kolmovskaya Street, 99 (formerly 65) Zabalkansky Prospekt, and 16-18 Zastavskaya Street.

In 1897, Euler \& Pastor changed its specialization and was renamed the Saint Petersburg Carriage Building Plant Association [9]. From that point onward, the plant started actively creating advanced workshops, equipped especially for carriage building. To support the further development of carriage building, there were plans to expand the plant with a carriage assembly, painting, and mechanical and fitting workshops [10]. In 1897, the Saint Petersburg Carriage Building Plant Association erected several fully fitted stone buildings on its premises: assembly workshops for 12 and 28 carriages respectively; a forge; a steam room; a boiler workshop; an upholstery and harness-making workshop; a woodworking workshop; a tin workshop, an administrative building (for plant management); a fitting-and-assembly workshop, a mechanical workshop with its own turning, machinery, and boiler rooms; a stock-keeping warehouse; an ice room and laundry; a carpentry workshop; as well as a wooden residential building and a storage room for iron [11].

In 1898, a new administrative building was added to the corner section of the premises, located at the crossing of Zabalkansky Prospekt and Zastavskaya Street. Three-story tall, with an attic level, the building was designed by engineer N.A. Arkhangelsky in 1896 and has survived to this day. The administrative building (115 Moskovsky Prospekt) stands a little to the side of the «red line»; its front brick facade faces Moskovsky Prospekt. While the building itself is quite utilitarian, the arched window openings and modest fine brick finishings give its facade a romantic, Renaissance-esque flair.

At the beginning of the $20^{\text {th }}$ century, the plant's premises were once again expanded, thanks to the purchase of additional land plots [12]. The following team members took part in designing the carriage building plant's workshops between 1897 and 1917:

- P.S. Samsonov (worked as a district technician for the city government between 1883 and 1907). He completed: the administrative building; the carriage assembly and wheel workshop; the turning/fitting/mechanical workshops;

- N.A. Arkhangelsky (worked as an engineer at the Saint Petersburg Fortress Engineering Headquarters and the $2^{\text {nd }}$ Saint Petersburg Engineering Division until 1898; in 1900-1908, worked as an architect at the Konstantinovskoye Artillery School; became an engineer at the construction department of the Main Directorate of Military Training Institutions in 1907; also served as deputy chairman of the City Duma and a member of the Provincial Zemstvo Assembly; known as an inventor, expert on roadworks and water supply; was mentioned in records as a member of several different societies and committees). He completed design of an extra story for the building at 99 
Zabalkansky Prospekt; design of an extra story for the mechanical workshop building (1896); carriage assembly workshops in Zastavskaya Street; and more;

- A.V. Drucker (technician, architect of the Imperial Academy of Sciences, the Nobles' Land Bank and the Peasants' Land Bank);

- V.V. Korvin-Krukovsky (civil engineer, served at the Technical and Construction Committee of the Ministry of the Interior and at the State Railway Administration from 1861 and after 1917; was also a technician and engineer at the Saint Petersburg City Government and architect at the construction department operated by the Office of the Institutions of Empress Maria). He completed design of the cast iron workshop; alterations in the window openings of the mechanical workshop; design of wagon workshop № 37 and workshop № 62);

- G.Kh. Rozovsky (civil engineer; architect of the Carriage Building Plant in the early $20^{\text {th }}$ century). He completed: several additional wings for the turning and mechanical workshop; reconstruction of the galvanizing workshop's southern wing (1912) and the fitting-and-assembly and painting workshops (1913-1914) [13]; overhaul of the coupling building (1915); an additional wing for the forge warehouse, and the merge between the carriage wheel workshop and the carriage painting workshop (1916);

- A.A. Chemesov, civil engineer, E.Yu. Gunst (process engineer in 1914), F.-I.D. Vodzyanitsky (technical engineer in 1903), I.I. Tejchma: contributed to the plans and estimates. The members of the latter group would also serve as Directors of the Carriage Building Plant in the early $20^{\text {th }}$ century, one after the other.

In 1915-1916, the old wooden structure was replaced with a stone counterpart, built upon iron pillars and within the same dimensions, and designed by G.Kh. Rozovsky. It was a typical example of retrospective architecture [14], with Romanesque motifs (wide groundfloor windows with a three-center arch on top, as well as with casings and keystones; rectangular windows styled after firing slits in a fortress; buttresses).

The plant's facilities all had their own operational purpose and possessed different layout and spatial features, but still belonged to a similar style, despite the diverse exteriors and silhouettes [15]. The rational spatial planning solutions and progressively designed roofs with skylights contrasted against Romanesque adornments: buttresses, slit windows, gables, rustic masonry, bow- and arch-shaped lintels, all of which made the facilities' design more retrospective. The structural solutions of the industrial wings were typical of the early $20^{\text {th }}$ century: metal pillar framework, metal trusses, length-wise skylights, north-light roofs. The window openings had divided glazing; many buildings had stained-glass windows, one of the hallmarks of Art Nouveau. The silhouettes varied, thanks to the abundance of pointed gables (a traditional feature of the Gothic Revival), double-pitch roofs, glass-paned skylights, triangular pediments, and chimney verticals [16]. All of these elements created a complex system with many dominant features and nuances.

By 1913, the plant, in a way, turned into a mini-town, filled with similarly scaled buildings of different types and functions, which, despite all these differences, made up an exceptionally harmonious, visually impressive whole (Fig. 1-3).

The revolution and the civil war brought Russian carriage building to a halt. But even despite the economic crisis, Petrograd (and then Leningrad) retained its status as an industrial hub after 1917. The Carriage Building Plant, claimed by the Soviet government in 1918, was renamed the Fifth State Mechanical and Carriage Plant. In 1922, it was further renamed after I.Ye. Yegorov, head of the labor strike movement. During this time period, the plant produced carriages for suburban and long-distance trains, as well as freight carriages and railway platforms [17].

The Great Patriotic War forced the factories and plants in Leningrad to switch to military production. The Yegorov Carriage Plant made ammunition and repaired tanks; it even had a special landmine division. More than 3000 bombs and shells were dropped on the plant during the war; many of its buildings got damaged already in 1941. The tool-building 
workshop was destroyed by a high-explosive bomb; the welding and assembly workshop and the woodworking workshop suffered as well. All wooden structures on the premises were taken apart for firewood. Still, the plant remained operational, despite the ceaseless bombing [18].

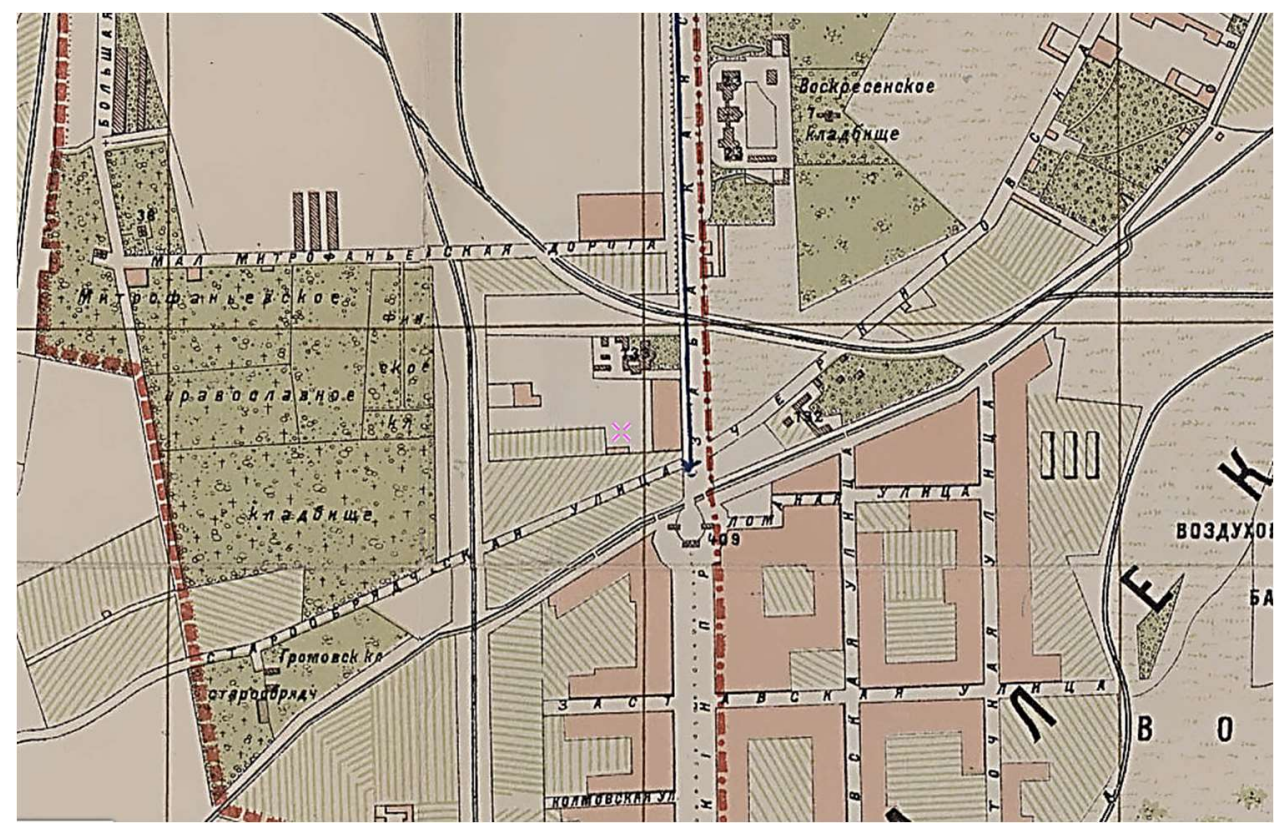

Fig. 1. 1884. Saint-Petersburg City Plan, published by Shchepansky (original map).

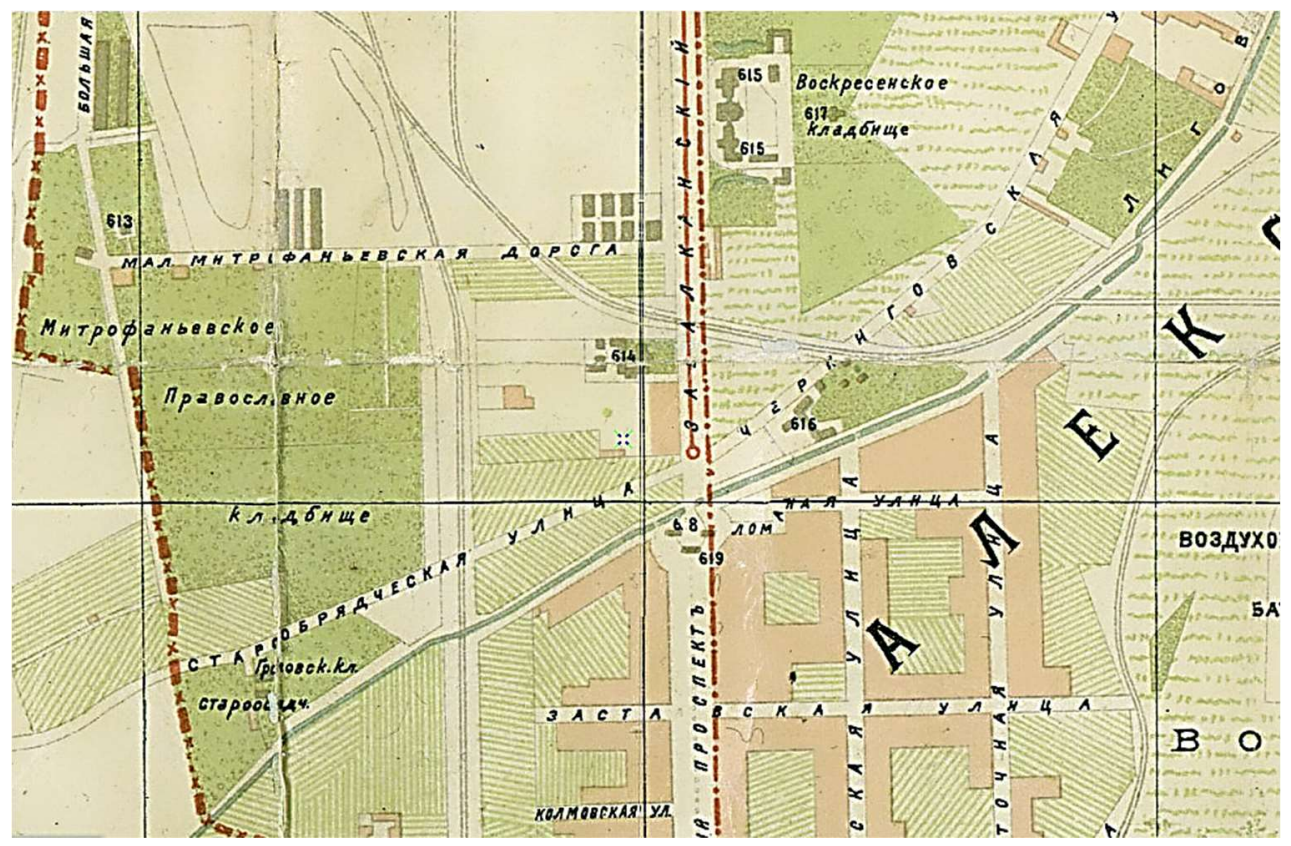

Fig. 2. 1903. Saint-Petersburg Plan; a supplement for Grigory Moskvich's tour guide (original map). 


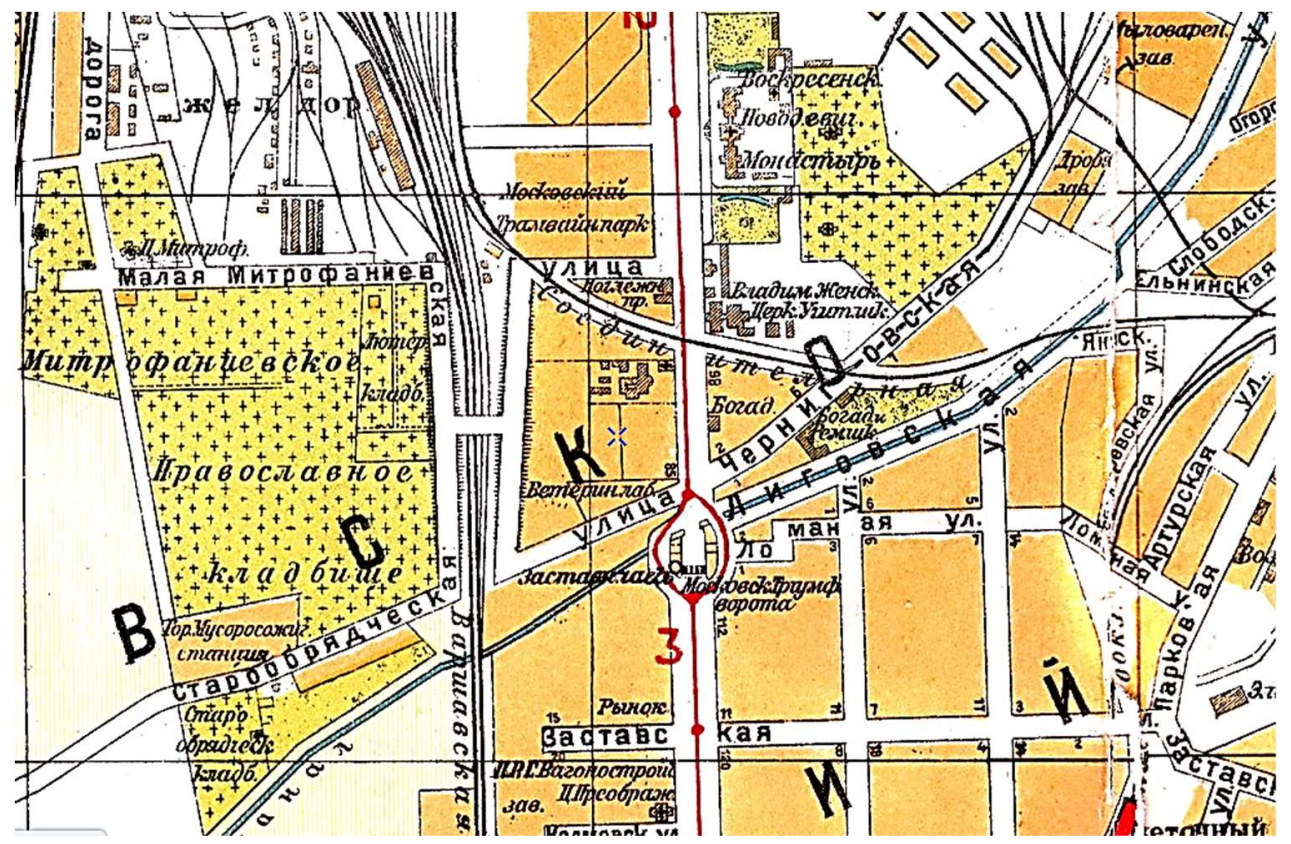

Fig. 3. Plan from the All of Leningrad tour guide (1925) (original map).

It was restored in 1949. The metal elements of many workshops were preserved. Moreover, they were supplemented by new interior design solutions: the wooden partitions typical of the 1950s. The workshops were repaired while retaining their spatial layout and authentic scale [19].

The plant was privatized at the beginning of the year 1990, but the production was put on hold during the ensuing crisis.

Operation resumed by 2000 , but the privatization of this architectural complex had irreversible consequences: the territory turned out to be so attractive to investors that the campaign to preserve its unique historical environment was doomed to fail from the outset [20]. We must note that this caused very little public outrage since the carriage building facilities were located in a restricted area. The plant's workers were the only people aware of what the production facilities, tucked away behind the front-facing administrative building, looked like. Paradoxically, the boundaries of the official heritage conservation zone (traced along Moskovsky Prospekt) were set up haphazardly, cutting right across the industrial buildings of the late $19^{\text {th }}$ and early $20^{\text {th }}$ century, which had been recognized as cultural heritage sites. The results did not take too long to manifest: the plant, with its sustainable, holistic environment and inimitable style, was turned into a construction site for a new residential complex. The heritage buildings that had weathered through revolutions and wars were unable to withstand the current generation's lust for profit [21]. Unfortunately, the authors are forced to conclude that this paper is not actually about architectural and urban planning evolution; it is about urban planning degradation. Most of the historical architecture of the plant complex was demolished in 2013.

\section{Conclusion}

The layout and volumetric-spatial composition of the carriage-building plant complex embodied the characteristic features of the architectural techniques of the late $19^{\text {th }}-$ early 
$20_{\text {th }}$ centuries, features of romanticism and retrospectivism. Due to the fact that the boundaries of the protective zone were approved without comparison with the protective boundaries of the local objects, the integrity of the complex was lost.

Obviously, it is important to consider as a good example of the conservation concepts already adopted for historic cities in Europe during the measures aimed at optimizing the industrial areas. It means the maximum preservation of the integral historical environment, its scale and «memory of the place», use of the historical heritage for socio-cultural purposes, preservation of the relationship between the historical environment and modern buildings in favor of the historical one.

\section{References}

1. V.I. Pilyavsky. Russian triumphal monuments (Leningrad: RSFSR Society for Promoting Political and Scientific Knowledge, Leningrad Department) (1960).

2. Russian State Historical Archive. Fund 350. List 94. Case 161. 1877. St. Petersburg Central State Historical Archive. Fund 513. List 127. Case 335. 1888. Fund 515. List 1. Case 5691. 1882-1897. Fund 1206. List 1. Case 234. (1893-1913).

3. General Plan of the Capital City of Saint Petersburg from Zuyev's Atlas. [online] Available at: http://www.etomesto.ru/map-peterburg_1858-zuev/. Date accessed: November 4, 2020.L. T. De Luca, Propulsion physics EDP Sciences, Les Ulis, (2009).

4. E. Vozniak, A. Butyrin. Classification of historical buildings façade's details on the basis of order theory, E3S Web of Conferences 91, 05016 (2019).

5. Y.S. Yankovskaya, A.G. Vaytens. Renovation of mass residential development in late 1950s-early 1970s in st. petersburg: Problems and perspectives, IOP Conference Series: Materials Science and Engineering 687 (5), (2019).

6. M. Zolotareva. Environmental planning and management of waterway construction (historical experience of Russia in the $18^{\text {th }}$ century and the beginning of the $19^{\text {th }}$ century), E3S Web of Conferences 91, 05023 (2019). DOI: 10.1051/e3sconf/20199105023

7. M.S. Stieglitz. Saint Petersburg's industrial architecture in the context of «industrial archeology» (Saint Petersburg: Beloye i Chernoye) (2003).

8. History of carriage building in Russia (until the early $20^{\text {th }}$ century). Available at: http:// rzd-expo.ru/history/istoriya_vagonostroeniya_Rossii/. Date accessed: November 4, (2020).

9. Carriage Building Plant. Plant management. Available at: https://www.citywalls.ru/ house5195.html. Date accessed: November 4, (2020).

10. S. Sementsov. Spatial development of Orthodox temple construction in Petrograd and its environs by 1917, E3S Web of Conferences 164, 4023 (2020).

11. St. Petersburg Central State Historical Archive. Fund 1206. List 1. Case 234.

12. M. Zolotareva. Space-planning development of high-rise dominating structures in the historical center (case study of St. Petersburg), E3S Web of Conferences 164, 4002 (2020). DOI: $10.1051 / \mathrm{e} 3$ sconf/202016404002

13. M.A. Granstrem. Areas of sustainable development in island districts of SaintPetersburg, IOP Conference Series: Materials Science and Engineering 775 (1), (2020). DOI: $10.1088 / 1757-899 X / 775 / 1 / 012087$.

14. M.N. Baryshnikov. Petersburg's business world (Saint Petersburg: Logos) (2000)

15. F.V. Perov, S.P. Zavarikhin, Y.I. Kurbatov. Principles of forming a polycentric system in a metropolis based on the reorganization of historical industrial areas (a case study of the Vyborgskaya Side in Saint Petersburg), IOP Conference Series: Materials Science and Engineering 775 (1), 12053 (2020). DOI: 10.1088/1757-899X/775/1/012053. 
16. V. Linov, D. Ivanov. Building up: Creating new homes on top of refurbished post-war estates, Proceedings of the Institution of Civil Engineers 171 (4), (2018). DOI: 10.1680 jcien.18.00006.

17. E. Vozniak, A. Burgundosova, A. Kopytova. Adaptation and reconstruction of the stations on the Finland railway road, MATEC Web of Conferences 239, 01016 (2018). DOI: $10.1051 /$ matecconf/201823901016.

18. St. Petersburg Central State Historical Archive. Fund 515. List 1. Case 5029 (1879-1897).

19. St. Petersburg Central State Historical Archive. Fund 513. List 145. Case 93. 1898; List 146. Case 332. 1899. Case 421. 1899. Fund 1206. List 1. Case 239. 1897. Case 243. 1898. Case 244. 1898. Case 247. 1899. Case 248. 1899-1912. List 2. Case 27. (1917).

20. St. Petersburg Central State Historical Archive. Fund 513. List 148. Case 145. 1902. Fund 1206. List 1. Case 261. (1903-1904).

21. S. Golovina, Y. Oblasov. The architecture and artistic features of high-rise buildings in USSR and the United States of America during the first half of the twentieth century, E3S Web of Conferences 33, 01032 (2018). 